\title{
PENERAPAN PUPUK HAYATI PADA TANAMAN PADI DI DESA TEGALMENGKEB KECAMATAN SELEMADEG TIMUR KABUPATEN TABANAN BALI
}

\author{
A.A.N.G. Suwastika ${ }^{1}$, I.K. Suada ${ }^{2}$, A.A.A.A.S. Sunari ${ }^{3}$, N.W.S. Sutari ${ }^{4}$
}

\begin{abstract}
ABSTRAK
Pengabdian kepada masyarakat dilaksanakan di Desa Tegalmengkeb, Kecamatan Selemadeg Timur, Kabupaten Tabaman, Bali. Tujuan dari pengabdian ini meningkatkan pemahaman dan keterampilan petani dalam penerapan pupuk hayati pada tanaman padi. Metode yang digunakan dalam kegiatan ini adalah penyuluhan dengan ceramah dan diskusi, dilanjutkan dengan pelatihan tentang pembuatan Mikro organisme Lokal (MOL) dan penerapan pupuk hayati pada tanaman padi. Diharapkan masyarakat dapat menerapkan teknologi pupuk hayati yang dapat meningkatkan hasil tanaman padi dan pendapatan petani. Hasil pelatihan meningkatkan pemahaman petani tentang pupuk hayati sebesar $30 \%$, tahu tentang pupuk hayati dan peran pupuk hayati sebagai penyubur tanah serta tanaman. Meningkatnya keterampilan petani dalam pembuatan Mikroorganisme Lokal (MOL) dan dapat menerapkan pupuk hayati Egary pada tanaman padi.
\end{abstract}

Kata Kunci: pupuk hayati, Mikroorganisme Lokal, Egary, tanaman padi sawah, pelatihan.

\begin{abstract}
Community service is implemented in Tegalmengkeb Village of East Selemadeg District Tabanan, Bali. The purpose of this dedication improves the understanding and skills of farmers in the application of biofertilizer on rice crops. The method used in this activity is counselling with lectures and discussions, followed by training on the manufacture of local microorganisms (MOL) and the application of biofertilizer on rice crops. It is hoped that the community can apply biofertilizer technology that can improve rice crop yield and farmer's income. The results of the training increase the understanding of farmers about biofertilizer by $30 \%$, know about the biofertilizer and the role of biofertilizer as fertilizer of soil and plants. Increased farmers' skills in the production of local microorganisms (MOL) and can apply Egary biofertilizer to rice crops.
\end{abstract}

Keywords: biofertilizer, Local Microorganism, Egary, rice field crop, training.

\section{PENDAhUluan}

Berdasarkan Profil Pemerintahan Desa Tegalmengkeb (2015), Desa Tegalmengkeb, Kecamatan Selemadeg Timur, Kabupaten Tabanan terletak $20 \mathrm{~km}$ dari pusat kota Tabanan. Merupakan daerah landai dengan ketinggian 200 meter di atas permukaan laut, curah hujan relatif sedang. Luas wilayah Desa Tegalmengkeb 549.363 ha dengan penduduk sebanyak 2.678 jiwa. Sebagian besar penduduk menggantungkan sumber pencarian di sektor pertanian, yaitu sebesar 512 orang $(72,5 \%)$

\footnotetext{
${ }^{1}$ Prodi Agroekoteknologi Fakultas Pertanian Universitas Udayana, Email: agungsuwastika@yahoo.co.id

${ }^{2}$ Prodi Agroekoteknologi Fakultas Pertanian Universitas Udayana, Email: ketutsuada@yahoo.com

${ }^{3}$ Prodi Agroekoteknologi Fakultas Pertanian Universitas Udayana, Email:gungsunari@yahoo.co.id

${ }^{4}$ Prodi Agroekoteknologi Fakultas Pertanian Universitas Udayana, Email: srisutaridharma@yahoo.com
} 
dan sektor lainnya seperti pegawai negeri, karyawan swasta dari berbagai sektor sebanyak 194 orang $(27,5 \%)$. Struktur perekonomian desa masih bercorak agraris yang meninitikberatkan pada sektor pertanian. Hal ini didukung oleh penggunaan lahan pertanian masih mempunyai porsi yang terbesar sebanyak $55,37 \%$ dari total penggunaan lahan desa, dan sebagian besar mata pencaharian penduduk menggantungkan hidup pada sektor pertanian. Komoditi yang menonjol sebagai hasil andalan adalah padi sawah.

Terjadi penurunan produktivitas padi sawah karena pemakaian pupuk kimia secara terus-menerus tanpa adanya pengembalian bahan organik ke dalam tanah dan kesulitan mendapatkan pupuk anorganik seperti urea, TSP, $\mathrm{KCl}$, dan pupuk anorganik lainnya pada saat tanam menyebabkan terjadinya penurunan hasil padi. Guna mengatasi permasahan tersebut perlu dicarikan solusi, salah satu cara yang dapat dilakukan dengan penerapan pupuk hayati. Pupuk hayati adalah pupuk yang mengandung jasad hidup maupun hasil kegiatannya yang apabila diberikan ke dalam tanah atau tanaman mampu meningkatkan kesuburan tanah dan hasil tanaman (Suwastika et al., 2012 \& Suwastika et al., 2013). Menurut Fernando et al.(2005 dalam Anesta et al.,2016), bahwa rizobakteri mampu memacu pertumbuhan tanaman, mampu menghasilkan atau mengubah konsentrasi hormon tanaman seperti asam indolasetat (IAA), asam giberelat, sitokinin dan etilen di dalam tanaman, mampu memfiksasi N2, memberi efek antagonis terhadap patogen tanaman dan diharapkan mampu menghasilkan benih yang bermutu.

Pupuk hayati yang dapat meningkatkan kesuburan tanah dan hasil tanaman diantaranya Egary, Mikroorganisme local (MOL), EM4 dll. Pemanfaatan pupuk hayati mampu memacu pertumbuhan dan hasil tanaman, sehingga mampu menurunkan penggunaan pupuk kimia anorganik pada tanaman padi. Juga mampu meningkatkan mutu benih, hal ini sesuai hasil penelitian Anesta dkk. (2016) bahwa penggunaan pupuk hayati Egary ditambah pupuk phonska dan urea masing-masing sebesar $100 \mathrm{~kg} / \mathrm{ha}$ mampu meningkatkan hasil tanaman padi P05 sebesar 1,0 ton/ha atau meningkat sebesar $38,46 \%$ dan perlakuan dengan pupuk hayati ditambah pupuk phonska dan urea masingmasing sebesar $200 \mathrm{~kg} / \mathrm{ha}$ mampu meningkatan hasil sebesar 0,7 ton/ha atau sebesar 33,99\% dibandingkan dengan control. Juga mampu meningkatkan mutu fisik dan fisiologis benih yaitu berat 1000 butir benih dan daya kecambah benih.

Berdasarkan uraian di atas, maka untuk meningkatkan kesadaran masyarakat petani di Desa Tegalmengkeb, Kecamatan Selemadeg, Kabupaten Tabanan pada penerapan pupuk hayati dilakukan penyuluhan dan pelatihan pembuatan MOL dan penerapan pupuk hayati pada tanaman padi. Tujuan dari kegiatan ini adalah untuk meningkatkan pemahaman petani tentang pupuk hayati dan meningkatkan pemahaman dan keterampilan petani dalam pembuatan MOL dan penerapan pupuk hayati pada tanaman padi.

\section{METODE PELAKSANAAN}

Metode yang digunakan dalam pelaksanaan kegiatan pengabdian pada masyarakat ini adalah penyuluhan dengan ceramah dan diskusi, serta demo tentang cara pembuatan MOL dan penerapan pupuk hayati pada tanaman padi dengan demplot. Pupuk hayati yang diberikan adalah MOL dan Egary.

Cara pembuatan mikroorganisme lokal (MOL) adalah sebagai berikut: Pembuatan MOL, dapat diperoleh dari bongkol pisang, limbah sayur atau buah, nasi basi, rebung bambu, pangkal batang rumput gajah atau daun gamal. Bahan ini dihancurkan dengan blender kemudian ditambahkan gula kepala/gula pasir dan direndam dalam air kelapa selama 10-14 hari sehingga terbentuk MOL yang banyak mengandung mikroba. Air kelapa merupakan sumber mineral sedangkan bonggol pisang, limbah sayur atau buah, rebung, rumput gajah atau daun gamal sebagai sumber hara dan energi, serta mikroba stater bio urine. Mikroba MOL diperoleh dengan cara memfermentasikan bahan- 
bahan tersebut di atas dalam jerigen/botol tertutup berisi 10 Liter air kelapa dimasukkan cincangan bahan MOL seberat 2500 gram dan gula , kemudian jerigen/botol ditutup dan diinkubasi selama 2 minggu sambil dikocok setiap hari. Setelah itu akan tampak bahan MOL hancur. Selanjutnya larutan diambil dan disaring untuk mendapatkan cairan bening yang akan digunakan sebagai pupuk hayati (Suwastika et al.,2015; Sutari, 2010)

Cara penerapan pupuk hayati pada tanaman padi adalah sebelum benih disemai maka benih yang sudah dalam kondisi emergence direndam dengan larutan pupuk hayati selama 30 menit. Hal ini bertujuan untuk meningkatkan daya tumbuh dan merangsang pertumbuhan akar tanaman padi. Pupuk hayati mengandung bakteri yang mempunyai kemampuan menghasilkan hormon tumbuh yang dapat merangsang pertumbuhan akar tanaman padi, sehingga tanaman akan tumbuh dengan baik. Pupuk anorganik diberikan sebanyak setengah dosis hanjuran. Dosis pupuk hanjuran adalah $200 \mathrm{~kg} / \mathrm{ha}$ pupuk ponska dan $200 \mathrm{~kg} / \mathrm{ha}$ pupuk urea. Pengaplikasian pupuk phonska dilakukan dua kali. Pemupukan dasar sebanyak $1 / 2$ dosis pada umur 7 hari setelah tanam (HST), dan pemupukan susulan sebanyak $1 / 2$ dosis pada umur 21 HST. Aplikasi pupuk urea diberikan tiga kali, pupuk dasar diberikan $1 / 3$ dosis pada umur 7 HST, pupuk susulan pertama $1 / 3$ dosis pada umur 21 HST, dan pupuk susulan kedua $1 / 3$ dosis pada umur 35 HST. Pada tahap awal dan akhir kegiatan dilakukan evaluasi melalui penyebaran kuisioner untuk mengetahui peningkatan pengetahuan dan pemahaman petani terhadap materi yang disampaikan.

\section{HASIL DAN PEMBAHASAN}

Pengabdian kepada masyarakat ini telah dilaksanakan di Balai Subak Gebang Gading Atas Br. Klecung Kaja, Desa Tegalmengkeb, Kecamatan Selemadeg Timur, Kabupaten Tabanan pada hari Sabtu, tanggal 12 Agustus 2017. Pelatihan diikuti oleh 27 orang petani yang sebagian besar dari anggota Subak Aseman 6 dan Subak Gebang Gading Atas Desa Tegal Mengkeb , dan empat orang dosen serta dua orang mahasiswa dari Fakultas Pertanian. Kegiatan ini sangat membantu petani dalam mengembangkan dan memajukan pertanian di desa dengan informasi dan teknologi serta temuan-temuan hasil penelitian di perguruan tinggi, yang selama ini telah dirasakan manfaatnya bagi kemajuan pertanian di perdesa, khususnya di Subak Gebang Gading Atas. Acara diawali dengan ceramah dan diskusi, serta demo tentang cara pembuatan MOL dan penerapan pupuk hayati pada tanaman padi. Pupuk hayati yang diberikan adalah MOL dan Egary. MOL bermanfaat dalam pembuatan pupuk organik dan sebagai pupuk probiotik. Selanjutnya dilakukan pelatihan pembuatan MOL dan penerapan pupuk hayati Egary pada tanaman padi. Dalam pelatihan ini diberikan cara sederhana pembuatan dekomposer sebagai bioaktivator dari bahan-bahan yang ada di lingkungan setempat, yaitu pembuatan mikroorganisme lokal (MOL) dengan teknologi yang sangat mudah diterapkan. MOL selain berperan sebagai aktivator juga dapat dimanfaatkan sebagai pupuk cair probiotik, karena mengandung unsur hara yang diperlukan oleh tanaman, juga mengandung jasad mikro yang mempunyai peran penting di dalam tanah sebagai pupuk hayati. Sedangkan pupuk hayati Egary mampu memacu pertumbuhan dan hasil tanaman, sehingga mampu menurunkan penggunaan pupuk kimia anorganik pada tanaman padi. Rizobakteri yang terdapat dalam Egary mampu menghasilkan atau mengubah konsentrasi hormon tanaman seperti asam indolasetat (IAA), asam giberelat, sitokinin dan etilen di dalam tanaman, mampu memfiksasi N2, memberi efek antagonis terhadap patogen tanaman dan diharapkan mampu menghasilkan benih yang bermutu, sehingga pertumbuhan dan hasil tanaman menjadi lebih baik.

Keberhasilan dari kegiatan pelatihan ini didukung oleh antusiasme peserta yang hadir pada waktu kegiatan berlangsung dan respons peserta terhadap materi yang diberikan. Diskusi berkembang, baik terhadap permasalahan yang berkaitan dengan materi pelatihan maupun terhadap permasalahan lainnya di bidang pertanian, seperti masalah budidaya dan serangan penyakit pada tanaman jagung dan tanaman kacang yang ditanam petani, serta keamanan penggunaan pestisida.

VOLUME 17 NOMOR 1, JANUARI 2018 | 116 
Berdasarkan hasil kuisioner yang diberikan menunjukkan bahwa pemahaman petani terhadap pupuk hayati dapat dirangkum sbb : 70\% petani tahu dengan pupuk hayati dan pupuk hayati dapat menyuburkan tanah serta bermanfaat bagi tanaman, sedangkan sebanyak 30\% tidak tahu. Sebanyak $50 \%$ petani pernah menggunakan pupuk hayati dan dari yang pernah menggunakan pupuk hayati mendapatkannya dengan membeli (70\%) sisanya (30\%) diberikan teman (Tabel 1). . Hal ini menunjukkan bahwa pemahaman petani tentang pupuk hayati meningkat sebesar $30 \%$, dari sebanyak $70 \%$ petani menjadi $100 \%$ tahu tentang pupuk hayati dan peran pupuk hayati dapat menyuburkan tanah serta tanaman. Berdasarkan Tabel 2 tentang persepsi peserta pelatihan terhadap Mikroorganisme Lokal (MOL) dan Egary, menunjukkan bahwa 80\% peserta pelatihan pernah mendengar tentang MOL, mendapatkan informasinya dari surat kabar/TV sebanyak $25 \%$, dari teman $37,5 \%$ dan melalui penyuluhan $37,5 \%$, serta selebihnya sebanyak $20 \%$ tidak pernah mendengar. Peserta pelatihan yang sudah tahu tentang MOL menyatakan $40 \%$ pernah menggunakan selebihnya sebanyak $60 \%$ tidak pernah menggunakannya dan menyatakan bahwa MOL dapat digunakan sebagai pupuk hayati (80\%), tidak dapat $(5 \%)$, dan tidak tahu $(15 \%)$. Sedangkan persepsi tentang pupuk hayati menunjukkan bahwa semua peserta pelatihan $(100 \%)$ tidak pernah mendengar/membaca tentang pupuk hayati Egary. Keterampilan petani dalam pembuatan Mikroorganisme Lokal (MOL) dan penerapan pupuk hayati Egary pada tanaman padi meningkat setelah dilakukan pelatihan. Egary sebagai pupuk hayati belum dikenal di kalangan petani, khususnya petani di Desa Tegalmengkeb, sehingga diperlukan sosialisasi lebih lanjut tentang pupuk Egary dan manfaatnya bagi tanaman padi. Bedasarkan persepsi peserta pelatihan terhadap kegiatan pelatihan yang dapat dilihat pada Tabel 3 menunjukkan bahwa peserta yang pernah mengikuti penyuluhan tentang pupuk hayati sebanyak $40 \%$ dan sebanyak $60 \%$ tidak pernah dengan alasan belum pernah diadakan. Semua peserta menyatakan dapat memahami materi yang diberikan, setuju dengan kegiatan pelatihan ini, serta kegiatan semacam ini perlu dilaksanakan lagi dikemudian hari.

Tabel 1. Data Pemahaman Peserta terhadap Pupuk Hayati

\begin{tabular}{|c|l|l|}
\hline No & Pemahaman terhadap pupuk hayati & Pilihan Peserta Pelatihan (\%) \\
\hline 1. & $\begin{array}{l}\text { Tahukah bapak/ibu/sdr apa yang disebut dengan pupuk } \\
\text { hayati }\end{array}$ & $\begin{array}{l}\text { a. Tahu (70) } \\
\text { b. Tidak tahu (30) }\end{array}$ \\
\hline 2. & $\begin{array}{l}\text { Tahukah bapak/ibu/sdr, bahwa pupuk hayati dapat } \\
\text { bermanfaat bagi tanaman? }\end{array}$ & $\begin{array}{l}\text { a. Tahu (70) } \\
\text { b. Tidak tahu (30) }\end{array}$ \\
\hline 3. & $\begin{array}{l}\text { Tahukah bapak/ibu/sdr, bahwa pupuk hayati dapat } \\
\text { menyuburkan tanah? }\end{array}$ & $\begin{array}{l}\text { a. Tahu (70) } \\
\text { b. Tidak tahu (30) }\end{array}$ \\
\hline 4. & Pernahkah bapak/ibu/sdr menggunakan pupuk hayati? & $\begin{array}{l}\text { a. Pernah (50) } \\
\text { b. Tidak pernah (50) }\end{array}$ \\
\hline 5. & Jika pernah, dari mana mendapatkannya? & $\begin{array}{l}\text { a. Membeli di pedagang (70) } \\
\text { b. Diberi teman (30) }\end{array}$ \\
\hline
\end{tabular}


Tabel 2. Data Persepsi Peserta terhadap Mikroorganisme Lokal (MOL) dan Egary

\begin{tabular}{|c|l|l|}
\hline No & Persepsi terhadap MOL & Pilihan Peserta Pelatihan (\%) \\
\hline 1. & $\begin{array}{l}\text { Pernahkah bp/ibu/sdr mendengar tentang MOL } \\
\text { (Mikroorganisme Lokal)? }\end{array}$ & $\begin{array}{l}\text { a. Pernah (80) } \\
\text { b. Tidak pernah }(20)\end{array}$ \\
\hline 2. & Jika pernah, dari mana mendapatkan informasi? & $\begin{array}{l}\text { a. Surat kabar/TV (25) } \\
\text { b. Dari teman }(37,5) \\
\text { c. Membuat sendiri }(37,5)\end{array}$ \\
\hline 3. & Pernahkah bp/ibu/sdr menggunakan MOL & $\begin{array}{l}\text { a. Pernah }(40) \\
\text { b. Tidak pernah }(60)\end{array}$ \\
\hline 4. & Jika pernah, dari mana mendapatkannya? & $\begin{array}{l}\text { a. Membeli di pedagang (0) } \\
\text { b. Diberi teman }(25) \\
\text { c. Membuat sendiri (75) }\end{array}$ \\
\hline 5. & $\begin{array}{l}\text { Dapatkah MOL digunakan sebagai pupuk hayati? } \\
\text { a. Dapat (80) } \\
\text { b. Tidak dapat (5) } \\
\text { c. Tidak tahu (15) }\end{array}$ \\
\hline 6. & $\begin{array}{l}\text { Pernahkah bapak/ibu/sdr mendengar/membaca } \\
\text { tetang pupuk hayati Egary dan manfaatnya? }\end{array}$ & $\begin{array}{l}\text { a. Pernah (0) } \\
\text { b. Tidak pernah (100) }\end{array}$ \\
\hline 7. & $\begin{array}{l}\text { Jika pernah, dari manakah bapak/ibu/sdr } \\
\text { mendapatkan informasi itu? }\end{array}$ & $\begin{array}{l}\text { a. Koran/majalah/TV } \\
\text { b. Poster/leaflet } \\
\text { c. Penyuluhan }\end{array}$ \\
\hline
\end{tabular}

Tabel 3. Data Persepsi Peserta terhadap Kegiatan Pelatihan

\begin{tabular}{|c|l|l|}
\hline No & Persepsi terhadap Pelatihan & Pilihan Peserta Pelatihan (\%) \\
\hline 1. & $\begin{array}{l}\text { Pernahkah bp/ibu/sdr mengikuti penyuluhan } \\
\text { tentang pupuk hayati? }\end{array}$ & $\begin{array}{l}\text { a. Pernah (40) } \\
\text { b. Tidak pernah (60) }\end{array}$ \\
\hline 2. & Apabila tidak pernah, apa alasannya? & $\begin{array}{l}\text { a. Belum pernah diadakan (100) } \\
\text { b. Tidak ada waktu (0) } \\
\text { c. Tidak penting (0) }\end{array}$ \\
\hline 3. & $\begin{array}{l}\text { Dalam penyuluhan dan pelatihan kali ini dapatkan } \\
\text { bp/ibu/sdr memahami materi yang diberikan? }\end{array}$ & $\begin{array}{l}\text { a. Dapat memahami (100) } \\
\text { b. Sulit memahami (0) }\end{array}$ \\
\hline 4. & $\begin{array}{l}\text { Setujukah bp/ibu/sdr dengan kegiatan ini? } \\
\text { a. Setuju (100) } \\
\text { b. Tidak setuju (0) }\end{array}$ \\
\hline 5. & $\begin{array}{l}\text { Perlukah kegiatan pelatihan semacam ini dilakukan } \\
\text { lagi? }\end{array}$ & $\begin{array}{l}\text { a. Perlu (100) } \\
\text { b. Tidak perlu (0) }\end{array}$ \\
\hline
\end{tabular}

\section{KESIMPULAN DAN SARAN}

Berdasarkan hasil pelatihan dapat disimpulkan sebagai berikut:

1. Pemahaman petani tentang pupuk hayati meningkat sebesar $30 \%$, tahu tentang pupuk hayati dan peran pupuk hayati dapat menyuburkan tanah serta tanaman.

2. Keterampilan petani dalam pembuatan Mikroorganisme Lokal (MOL) meningkat setelah pelatihan dan dapat menerapkan pupuk hayati Egary pada tanaman padi.

3. Semua peserta menyatakan dapat memahami materi yang diberikan, setuju dengan kegiatan pelatihan ini, serta kegiatan semacam ini perlu dilaksanakan lagi dikemudian hari

Egary sebagai pupuk hayati belum dikenal di kalangan petani, khususnya petani di Desa Tegalmengkeb, sehingga diperlukan sosialisasi lebih lanjut tentang pupuk Egary dan manfaatnya bagi tanaman padi. 


\section{UCAPAN TERIMAKASIH}

Terima kasih kami ucapkan kepada Dekan Fakultas Pertanian, Ketua LPPM dan Rektor Universitas Udayana yang telah memfasilitasi dan mendanai kegiatan ini sehingga kegiatan dapat berjalan dengan baik dan lancar.

\section{DAFTAR PUSTAKA}

Anesta, D. O., I D. N. Nyana \& A.A. M. Astiningsih. 2016. Studi Hasil Dan Kualitas Benih Padi P05 Dengan Pemberian Pupuk Hayati (Enterobacter Cloacae). E-Jurnal groekoteknologi Tropika ISSN: 2301-6515 Vol. 5, No. 2, April 2016.

Suwastika, A.A.N.G, N. N. Soniari\& A.A.I. Kesumadewi. 2012. Biologi Tanah. Program Studi Agroekoteknologi Fakultas Pertanian Universitas Udayana.

Suwastika, A.A.N.G., N.W.S. Sutari, A.A.A.A.S. Sunari, N.N. Soniari \& I W.D. Atmaja. 2013. Pengolahan Limbah Pertanian dan Kerajinan menjadi Pupuk organik Berkualitas di Desa Taro, Kecamatan Tegallalang Kabupaten Gianyar. Udayana Mengabdi 12 (1); 16-19.

Suwastika, A.A.N.G., N.W.S. Sutari \& N.W. Muriani. 2015. Analisis Kualitas Larutan Mikroorganisme Lokal Daun Gamal (Gliricidia sepium) pada beberapa waktu Inkubasi. Agrotrop, 5 (2): 208-217.

Widarma, I D.M. 2015. Propil Pemerintahan Desa Tegalmengkeb, Kecamatan Selemadeg Timur Kabupaten Tabanan. 